\title{
Restitutionary Remedies in the Contractual Context
}

The final version of this article is at (2103) 76 MLR 429

\section{Introduction}

The standard remedies in contract, expectation damages and specific performance, give the claimant the benefit of the performance of the contract by putting him in the position he would have been in if the contract had been performed. ${ }^{1}$ There are other remedies that sometimes arise out of a contract, or "in a contractual context", ${ }^{2}$ that do not have this effect. Where the claimant has made a payment to the defendant under the contract, and has not received the performance due to him in return, he may be able to recover the payment. ${ }^{3}$ Similarly, where the claimant has supplied goods or services under the contract and the defendant has not paid or become liable to pay under a payment clause, the claimant may be entitled to reasonable payment for what he has done in the form of a quantum meruit. ${ }^{4}$ These remedies are commonly described as restitutionary remedies, and I will use this expression, though, as I will suggest below, it is not always apt.

It has been controversial whether a claim for a restitutionary remedy in the contractual context should be understood as a contractual claim or an unjust enrichment claim, and it is also controversial whether and why this issue is of any significance. As a matter of first impression, one might say that a claim for a restitutionary remedy arising in these circumstances is a contractual claim, simply because it arises out of a contract, as a result of the fact that the contract has not been performed as the parties envisaged. But it is widely thought that the claim cannot be contractual. First, the restitutionary remedy does not appear to be a remedy for a breach of contract, because it does not serve to undo or correct the

\footnotetext{
${ }^{1}$ It is not necessary for present purposes to deal with the payment of an accrued debt separately. 2 This neutral expression is used in TA Baloch, Unjust Enrichment and Contract (Hart, 2009), 1. On my usage it includes claims arising on frustration.

3 e.g. Rowland v Divall [1923] 2 KB 500.

4 e.g. De Bernady $v$ Harding (1853) 8 Exch 822. For convenience, I use "quantum meruit" to include payment for goods or goods and services under the contract. The article is not concerned with an implied term for reasonable payment where the contract does not specify a price.
} 
breach of duty or its consequences, by putting the claimant in the position he would have been in if the contractual duty had been performed. Secondly, it does not necessarily arise from a breach by the defendant of his contractual duty of performance. ${ }^{5}$ It can arise on the frustration of the contract, ${ }^{6}$ where the defendant has not committed a breach, and even where it is the claimant rather than the defendant who has breached the contract. ${ }^{7}$ Furthermore, the restitutionary remedies that arise when a valid contract terminates seem to be the same as or very similar to the remedies that arise in respect of part performance when a contract is void or is voidable and has been rescinded, and here the claim is clearly non-contractual. Indeed, they seem to be the same or very similar to the remedy that arises to undo a mistaken payment, which has no connection with contract at all. A claim for a restitutionary remedy is nowadays generally taken to be based, instead, on the principle of unjust enrichment, on the fact that the defendant has received a benefit that in justice he ought to surrender or pay for. ${ }^{8}$ This approach is, of course, an aspect of the modern recognition of a general category of unjust enrichment in the common law. If the claim for a restitutionary remedy is based on a principle of unjust enrichment, the restitutionary remedies have to be understood as requiring the defendant to give up or pay for the benefit he has received, ${ }^{9}$ but it is not at all clear that this how they should be understood. On the face of it, the recovery of a payment is open to interpretation either as removing a benefit or restoring a loss, and similarly the quantum meruit seems open to interpretation either as the removal of, or payment for, a benefit, or as payment for what the claimant has

\footnotetext{
${ }^{5}$ See e.g. P Birks, "Restitution and the Freedom of Contract" [1983] CLP 141.

6 Fibrosa Spolka Akcjna v Fairburn Lawson Combe Barbour Ltd [1943] AC 32, and the Law Reform (Frustrated Contracts) Act 1943.

7 Dies v British and International Mining and Finance Co [1939] 1 KB 724

8 See, for example, A Burrows, The Law of Restitution (OUP, $3^{\text {rd }}$ edn, 2011), 319; G Virgo, The Principles of the Law of Restitution (OUP, $2^{\text {nd }}$ edn, 2006), 304-5; J Beatson et al, Anson's Law of Contract (OUP, 29 $9^{\text {th }}$ edn, 2010), 587; Baloch, above n2, 67, 178-80; A Skelton, Restitution and Contract (Mansfield Press, 1998); E Peel, Treitel, The Law of Contract (Sweet \& Maxwell, $13^{\text {th }}$ edn, 2011), 22-001.

9 The restitutionary remedy is often said to reverse a transfer or return a benefit, and this makes sense when the claimant has made a transfer of money or goods to the defendant, but in the case of providing services it is misleading to speak of reversing a transfer or returning the services as opposed to paying for them: see, for example, S Stoljar, The Law of Quasi-Contract (The Law Book Co., $2^{\text {nd }}$ edn, 1989), 197-9.
} 
done, including compensation for his expenses. Furthermore, it seems possible that there should be a claim where no benefit has yet been conferred on the defendant. ${ }^{10}$

Sometimes a contracting party has a claim for disgorgement. By this expression, I mean the removal of the profit made by the defendant through a wrong. It is not the same thing as a restitutionary remedy, though it is also sometimes said to be a response to unjust enrichment, and it may be equivalent to a restitutionary remedy in some circumstances. A restitutionary remedy serves to satisfy an interest of the claimant, by returning the claimant's payment to him, or providing him with payment for work done or a benefit conferred, and it need not arise from a wrong. Disgorgement is necessarily a response to a wrong by the defendant and it focuses on preventing the defendant from profiting through the wrong, from which the claimant is in effect an accidental beneficiary. ${ }^{11}$ I shall not consider disgorgement save where it is relevant to the discussion of restitutionary remedies.

In this article, I will explain why a claim for a restitutionary remedy in the contractual context should be understood as a contractual claim and not as an unjust enrichment claim, and why it is important which analysis is adopted. Two underlying issues are considered in the next two sections of the article. The first is the nature and significance of "doctrinal categories" such as contract and unjust enrichment - what it means to say that a claim arises in a certain doctrinal category such as contract or unjust enrichment. The second is the relationship between "rights and remedies", or more accurately, primary and remedial rights, which in contract would ordinarily be understood to mean the relationship

\footnotetext{
10 Planché $v$ Colburn (1831) 8 Bing 14 is usually understood in this way.

11 The restitutionary remedies have traditionally taken the form of a quantum meruit or money had and received, but where disgorgement has been allowed it has taken the form of an account of profits or constructive trust. Until recently, the position was that disgorgement was not available at all for breach of contract; now there is limited availability under Attorney General v Blake [2000] 3 WLR 625. A similar usage is adopted in LD Smith, "The Province of the Law of Restitution" (1992) 71 Can Bar Rev 672; P Jaffey, "Restitutionary Damages and Disgorgement" [1995] RLR 30; S Worthington "Reconsidering Disgorgement for Wrongs" (1999) 62 MLR 218; J Edelman, Gain-Based Damages (Hart, Oxford, 2002). Disgorgement in this sense is not best described as a remedy at all, because it does not serve to satisfy or fulfil C's primary right in the particular sense of securing to $C$ the benefit of the right.
} 
between the primary right to performance and the right to a remedy such as compensation or specific performance that arises when the contract is breached. In the subsequent sections, I will deal with the unjust enrichment account of the claim for a restitutionary remedy in the contractual context, and then a suggested contractual account. ${ }^{12}$

\section{Doctrinal categories}

The nature of doctrinal categories is not often explicitly considered, but it is clearly in issue in disputes about the classification of a claim in contract or unjust enrichment. The approach I suggest below to doctrinal categories, although it is not consistent with all writing on this question, seems to me to be the only way of making sense of this sort of dispute, and more generally of the way in which doctrinal categories are invoked in legal reasoning and they way they evolve.

A doctrinal category is commonly understood as a body of rules that operates as an autonomous category to determine when a claim arises, so that whether a claim arises on certain facts is assessed by reference to a particular doctrinal category, or particular doctrinal categories considered separately. Thus a doctrinal category is also a category of cause of action. This is understandable on the basis that a doctrinal category consists of the rules that give effect to a certain principle of liability, in order to remedy a certain type of injustice. Contract law is of course generally understood as a body of rules that give effect in law to the principle that people should keep their agreements, and the rules of contract law determine how the principle is applied - what counts as an agreement, when an agreement is enforceable, what remedies are available if the agreement is not performed, etc. One might say, along the same lines, that negligence in tort is a doctrinal category based on a principle that one should bear the risk of foreseeable losses caused by one's careless or unreasonable behaviour, and that

\footnotetext{
12 The suggested account is a version of an approach previously proposed: see P Jaffey, The Nature
} and Scope of Restitution (Hart, 2000), ch 2. 
unjust enrichment is a category based on a principle that justifies claims arising from the defendant's receipt of a benefit. ${ }^{13}$ Within these categories, the rules laid down by the courts deal with different aspects of the principle of liability, as they have arisen across the range of circumstances in which the principle can apply. On this understanding one might aptly describe a doctrinal category as a "justificatory category". ${ }^{14}$

Of course, courts do not begin by identifying such a principle of liability and then construct a body of rules to give effect to it, that is to say, doctrinal categories are not usually constructed "top-down". ${ }^{15}$ They emerge out of the ordinary development of the law by analogical reasoning in individual decisions, on particular facts. Through analogical reasoning, courts extend and qualify existing rules by equating new cases with previous cases, or distinguishing them. The rules of the category deal with materially different situations, but all the cases falling in the category are mutually analogous in the sense that they involve the application of the same principle of liability. ${ }^{16}$

This approach is consistent with the fact that the principle of liability may not be explicitly stated, and that it may be contentious, and that there can be contested parts of the law, whose proper classification is a matter of dispute. It is also consistent with the fact that doctrinal categories can appear and disappear in the development of the law. In particular, a new doctrinal category can be created by bringing together, under a common set of rules, various pockets of law or "doctrinal fragments" that were developed quite independently, ${ }^{17}$ by recognising them as analogous and based on a common principle of liability. This is what appears to have happened in the development of the law of unjust enrichment

\footnotetext{
13 See also Deane J's statement of the principle in Pavey \& Matthews Pty Ltd $v$ Paul (1987) 162 CLR $221,256-7$.

14 See P Jaffey, Private Law and Property Claims (Hart, 2007), ch 1.

15 This expression was used in Lumbers $v$ W Cook Builders Pty Ltd 232 CLR 635 (HC Aust) in a judgement critical of the recognition of a doctrinal category of unjust enrichment.

16 For example, according to Birks, the law of unjust enrichment is "the law of all events materially identical to the mistaken payment of a non-existent debt": P Birks, Unjust Enrichment (Clarendon Press, $2^{\text {nd }}$ edn, 2005), 3.

17 The expression is used in E Weinrib, "Correctively Unjust Enrichment", in R Chambers, C Mitchell \& J Penner, eds, The Philosophical Foundations of the Law of Unjust Enrichment (OUP, 2009); and "The Disintegration of Duty" in M Stuart Madden, ed., Exploring Tort Law (2005).
} 
out of various doctrinal fragments, such as the law on mistaken payments, tracing claims, mistakenly provided services, subrogation, and necessitous intervention, as well as the restitutionary remedies in the contractual context. A development of this sort, concerning the organisation and classification of claims, goes beyond qualifying and extending rules through ordinary analogical reasoning in an incremental way. It inevitably involves an element of "top-down" reasoning, involving the reinterpretation and reorganisation of a doctrinal category through a consideration of the principle of liability.

One might object that what really matters in practice is simply whether a claim is available in particular circumstances, not which doctrinal category it falls under. On the suggested approach, however, doctrinal categories play a practical role in determining when a claim arises, by way of analogical reasoning where the law is unsettled. When it is unclear whether a claim is available on the facts, a judge will consider whether the rules of one or other doctrinal category can be developed to accommodate a claim on the facts. The underlying issue is whether the principle of liability supports a claim and whether the rules should be developed to this effect. In this way the currently-recognised doctrinal categories limit and guide the development of the law through analogical reasoning. This role of doctrinal categories is in principle defensible only if a doctrinal category is indeed a justificatory category, based on a certain principle of liability.

It seems to me that this general understanding of the nature of a doctrinal category and its role in legal reasoning is the only way to make sense of the controversy over the claim to a restitutionary remedy in the contractual context. Whether the claim is properly understood as a contractual claim or an unjust enrichment claim depends on the principle of liability it is based on. In practice, the issue will arise in connection with a claim in particular circumstances in which the law is unsettled, and as part of its reasoning the court may be drawn into considering whether the claim is a matter of contract or unjust enrichment. In the end, the answer lies in exploring the principles of liability, the contractual principle 
and the principle of unjust enrichment, to see which can provide a justification for the claim, and so in what circumstances the claim should arise.

Although unjust enrichment has become established as a doctrinal category in English law, it is fair to say that it remains controversial whether the category is sound ${ }^{18}$ - whether the various types of case that have in modern times been brought together to form the category are really based on the same general principle of liability, or, in other words, whether these cases are analogous to each other. The problem is that, unlike the principles stated above for contract and for negligence (whatever controversy may attach to them), the principle of unjust enrichment does not appear to have been expressed in a transparent form, capable of being employed to support and guide the development of a body of rules and a type of claim. To say that there is a principle of unjust enrichment is not in itself to state what the principle is. If there is a principle, it remains obscure, ${ }^{19}$ though some insist that it will be revealed through further work. ${ }^{20}$ Possibly some writers who regard themselves as supporters of the doctrinal category of unjust enrichment would deny that there is a principle of unjust enrichment in the sense of a general principle of liability, and would say instead that the law of unjust enrichment is a collection of different types of claim based on different principles of liability. ${ }^{21}$ On this view, one might say that the category of unjust enrichment is like tort rather than contract, tort being, it might be argued, a category that encompasses a number of distinct principles of liability. ${ }^{22}$ This may well be the right way to understand tort law, and if so tort law is not a doctrinal category in the particular sense I have adopted (though

\footnotetext{
18 There have been numerous enrichment sceptics, including J Dietrich, Restitution: A New Perspective (Federation Press, 1998); S Hedley, Restitution: Its Division and Ordering (Sweet \& Maxwell, 2001); IM Jackman, The Varieties of Restitution (The Federation Press, 1998); Stoljar, above n9; Jaffey, above n12, and above n14.

19 Some possibilities are considered sceptically in Jaffey, above n14, Ch 8.

20 R Stevens, "Is there a Law of Unjust Enrichment?" in S Degeling \& J Edelman, eds., Unjust Enrichment in Commercial Law (Thomson, 2008), 34.

${ }^{21}$ Possibly this is the implication of the "unjust factors" approach to unjust enrichment claims. This approach is the established one, though under pressure from the "absence of basis" approach: see Burrows, above n8, ch 5 . The relationship between this question and the nature of the principle of liability is obscure.

${ }_{22}$ See, for example, the discussion in SA Smith, "Unjust Enrichment: Nearer to Tort than Contract" in Chambers et al, above n17.
} 
negligence in tort law does seem to me to be a doctrinal category in this sense, and some writers think that much of tort law should be governed by a principle of negligence and subsumed into a doctrinal category of negligence). In any case, the particular role of a doctrinal category in legal reasoning depends on whether it is a justificatory category based on a common principle of liability. Only if unjust enrichment is such a category does it make sense to treat all cases in the category as mutually analogous and bring them together under a common body of rules, or to contrast an unjust enrichment claim with a claim in contract, or, in short, to recognise a cause of action in unjust enrichment. To say that a particular claim is an unjust enrichment claim, meaning that the cause of action is in unjust enrichment, implies that the claim is based on a particular principle of liability, and if it is contentious whether the claim is an unjust enrichment claim or in what circumstances it should arise, the solution lies in investigating the principle of liability. ${ }^{23}$

It seems very plausible that what cases of unjust enrichment really have in common is not a principle of liability but a type of remedy. This is of course consistent with the fact that what is now commonly described as the law of unjust enrichment was until recently described as the law of restitution, and developed to address the problem of explaining various types of claim that had a certain remedy in common, namely restitution, understood as the remedy of requiring a defendant to surrender a benefit received or to pay for it. ${ }^{24}$ If it is the type of remedy that characterises the law of unjust enrichment, and not a justifying principle, it is a mistake to recognise it as a doctrinal category, just as it would be a mistake, say, to unify contract and negligence on the ground that they generally

\footnotetext{
${ }^{23}$ According to Burrows, the role of the principle of unjust enrichment is as "an organising tool" for legal decisions, and in this role the principle "enables one to see which are the like cases that should be treated alike", presumably in order to account for previous decisions and to guide future decisionmaking: see Burrows, above n8, 4. But whether cases are alike or unlike - analogous or not - depends on the basis on which they are compared, and if they are organised with a view to accounting for previous decisions and guiding future decision-making then the organising principle is, or purports to be, a principle of liability and the category a justificatory category.

${ }_{24}$ Or maybe it would be better to say a group of benefit-based remedies.
} 
involve the same remedy of compensation. ${ }^{25}$ If the category is not well founded, its recognition obscures the true basis for claims brought into the category and obstructs the sound development of the law. I shall not consider the principle of unjust enrichment generally, but in the second half of the article I consider how the principle of unjust enrichment might be understood in the contractual context, and also the nature of the contractual principle, the principle of agreement.

\section{The relationship between primary and remedial rights}

According to Baloch, a claim for a restitutionary remedy arising out of a contract cannot be contractual because there was no agreement over the remedy. ${ }^{26}$ The parties did not agree that a restitutionary remedy would arise in particular circumstances, and any attempt to construe the contract to evince such an intention is unrealistic: the parties are unlikely to have considered the point. Since contract law is concerned with giving effect to the parties' agreement, it follows, according to Baloch, that the claim for a restitutionary remedy cannot be contractual. But to say that contract law is about giving effect to the parties' agreement is not to say that only agreed remedies are contractual. After all, the parties do not usually make any agreement concerning specific performance or expectation damages, and yet no-one doubts that a claim for one of these is a contractual claim. What is necessary for a claim for a certain remedy to be contractual is not that the remedy was agreed, but that the remedy serves to protect and give effect to rights arising by virtue of the agreement - it has to be, I will say, a remedy that vindicates contractual rights. The argument against the contractual analysis is not that restitutionary remedies are not agreed remedies, but that, unlike the ordinary contract remedies, they cannot be understood as

\footnotetext{
25 Thus it is tempting to think that proponents of the theory of unjust enrichment have been deceived by the "remedy-as-justification" fallacy, the fallacy of mistaking a remedial category of claims for a justificatory category: see Jaffey, above n14, 17 . This objection gains support from the way in which the principle of unjust enrichment is often expressed, as the principle that unjust enrichments should be reversed or undone: see, for example, Burrows, above n8, 4 .

26 Baloch, above n2, 179.
} 
vindicating contractual rights. This point calls for some consideration of the relationship between "rights and remedies", or primary and remedial rights. ${ }^{27}$

According to what I will refer to as the standard analysis of contract, a contract is a legally enforceable agreement, and an agreement is an exchange of promises, which generate duties to perform. ${ }^{28}$ The primary relation in contract consists of the defendant's duty of performance and the claimant's correlative right to performance. A claim arises from a wrong, consisting of a breach of the duty, and the appropriate remedy is to require the defendant to perform his duty or, more usually, to pay compensation to the claimant measured by what is necessary to put the claimant in the position he would have been in if the duty had been performed. ${ }^{29}$ These remedies, expectation damages and specific performance, are apt contractual remedies because they serve to protect and fulfil the primary relation in contract, that is to say they vindicate the primary right of the claimant. In more general terms, one can say that a remedial right or claim - the right to a remedy - arises to remedy an injustice, meaning not an injustice in the abstract, but an injustice defined by the primary relation between the parties, here a contractual injustice. A contractual injustice is the breach of a contractual duty and its result for the claimant, viz., the fact that he does not receive the contractual performance due to him. A claim in contract cannot arise by virtue of any other sort of injustice. If a remedy is justified in the contractual context but cannot be explained as a remedy for a contractual injustice, there must be some other, non-contractual injustice to account for it, that is to say an injustice arising under a different principle of liability, and the claim must be in a different doctrinal category.

Consider reliance damages. On the standard analysis of contract, the appropriate measure of damages is the expectation measure, because this

\footnotetext{
27 This line of argument is pursued at greater length in Jaffey, above n14, Ch 2, in connection with the idea of remedial "monism" and "dualism".

28 See e.g. D McLauchlan, "Reliance Damages for Breach of Contract" [2007] NZLR 417; D

Friedmann,"The Performance Interest in Contract Damages" (1995) 111 LQR 628; C Fried, Contract as Promise (Harvard University Press, 1981).

${ }_{29}$ Robinson v Harman (1848) 1 Ex 850, 855, per Parke B; The Golden Victory [2007] 2 AC 353.
} 
represents the value to the claimant of the performance of the primary duty and so is apt to correct the contractual injustice. The reliance measure of damages typically compensation for loss in the form of expenditure the claimant has incurred in performing the contract - is not on the face of it appropriate because it does not reflect the value of the performance of the primary duty: the remedy does not correct a contractual injustice and thereby vindicate a contractual right. But a claimant is allowed to recover reliance damages and the justification is said to be that they are a proxy for expectation damages. ${ }^{30}$ This is plausible on the basis that, where it is difficult for the claimant to prove expectation damages, there should be a "presumption of recoupment" in his favour, ${ }^{31}$ that is to say a presumption that the contract would have been a profitable one for the claimant, so that if it had gone to completion he would have received a benefit worth more to him than his own cost of performance. But if the claimant has made a losing contract - he would have made a loss if the contract had been completed - he should not be able to recover all of his reliance loss. This would allow him to recover compensation for a loss that he incurred because he made a losing contract, not because the defendant failed to perform. In other words, it would not remedy a contractual injustice. Thus the reliance measure should be capped at the expectation measure, if the defendant can establish this, and this is indeed the rule in this situation. ${ }^{32}$

To put it another way, under the standard analysis there is no right to reliance damages as such. Reliance damages are relevant only because they play a part in determining the expectation measure, using the presumption of recoupment. The reliance measure does not give effect to an alternative principle of recovery, or protect a distinct "reliance interest" under the contract, ${ }^{33}$ since this

\footnotetext{
30 Anson, above n8, 542.

31 McLauchlan, above n28, 427.

32 C \& P Haulage v Middleton [1983] 1 WLR 1461; CCC Films (London) Ltd v Impact Quandrant Films Ltd [1985] QB 16; Commonwealth of Australia v Amann Aviation Pty Ltd (1991) 104 ALR 1.

33 The approach in LL Fuller \& WR Perdue, "The Reliance Interest in Contract Damages" (1936) 46 Yale LJ 52, 373.
} 
would make no sense of the cap. ${ }^{34}$ Reliance losses are merely "a species of expectation losses", ${ }^{35}$ or a means for assessing them, and in the end there is only the right to receive performance, for which the appropriate remedy is specific performance or expectation damages.

The point can be made in terms of allocation of risk under the contract. If the claimant, C, has a duty under the contract to provide the defendant, D, with a certain benefit at an agreed price, $\mathrm{C}$ takes the risk of an increase in the cost of providing the benefit, and $D$ takes the risk that the value of the benefit to him will fall. If the contract is not performed as agreed, this allocation of risk is enforced only if the remedial regime properly reflects the primary relation. If this is not the case, the allocation of risk is subverted. Uncapped reliance damages for $\mathrm{C}$, where C has spent more than he envisaged on providing the benefit, would subvert the contractual allocation of risk, because under the standard analysis the contract allocates to $D$ only the risk of loss to $C$ relative to the position $C$ would have been in if the contract had been completed.

Under the standard analysis, a restitutionary remedy for the recovery of a prepayment does not correct a contractual injustice by securing to the claimant the performance of the duty he was owed or its value. In other words, protecting a "restitution interest" as an interest under the contract is incompatible with the standard analysis, just as protecting a reliance interest is. ${ }^{36}$ Furthermore, a restitutionary remedy cannot be understood, in the way that reliance damages are understood, as a proxy for expectation damages in cases where the expectation measure is hard to establish, because it is clear that the amount of the payment recovered can exceed the expectation measure, as where the claimant recovers the price paid in advance for goods that are not delivered and are now worth less than this. There is no suggestion here that the measure of recovery should be capped. Thus it seems that the remedy cannot be contractual.

\footnotetext{
34 See McLauchlan, above n28, 420, 457; Treitel, above n8, 20-029; The Mamola Challenger [2010] EWHC 2026.

35 The Mamola Challenger, ibid, para 42.

36 This idea is derived from Fuller \& Perdue, above n33.
} 
It would be unjustified as a contractual remedy because its effect is to subvert the contractual allocation of risk by allowing the claimant to recover for a loss for which he bears the risk under the contract.

It is sometimes said that a quantum meruit is consistent with the contract if it is subject to the "contractual valuation", that is to say if the measure of the quantum meruit reflects the value placed on the work by the contract, which is usually understood to mean that it is measured pro rata, as a proportionate part of the contract price for the whole performance due, whereas if the quantum meruit is measured according to a current market rate for the work done, independently of the contract, it is inconsistent with the contract and subverts the contractual allocation of risk. ${ }^{37}$ But again, under the standard analysis of contract there is no room for a quantum meruit as a contractual remedy at all, because the quantum meruit does not respond to a contractual injustice - it does not correct a breach of the duty to perform by putting the claimant in the position he would have been in if the contract had been performed - unless, again, it can be regarded, like reliance damages, as a proxy for expectation damages in cases where the expectation measure is hard to establish, or the contract provides, expressly or impliedly, for a duty to pay for the work done so far.

If it is right that a claim for a restitutionary remedy should sometimes be available in the contractual context, it seems that it cannot be a contractual claim responding to a contractual injustice, and there must be a different principle of liability - presumably the principle of unjust enrichment - operating in this context. This would mean that there are two different regimes operating with respect to contractual non-performance, the contractual regime with expectation damages and specific performance, and the unjust enrichment regime with restitutionary remedies.

\footnotetext{
37 See e.g. J Beatson, "The Temptation of Elegance: Concurrence of Restitutionary and Contractual Claims" in W Swadling \& G Jones, eds, The Search for Principle (OUP, 1999), 143. A similar article is published as "Restitution and Contract: Non-Cumul?" (2000) 1 Theoretical Inquries in Law 83.
} 
The usual view is that, if the contract has not been terminated and continues in full force, there is no room for a restitutionary remedy, because the defendant's liability to a restitutionary remedy would be inconsistent with his continuing duty to perform the contract. Following termination, however, the contract has become ineffective and, in the absence of a duty to perform the contract, the defendant can be liable to a restitutionary remedy without any inconsistency. Now there is merely a choice of claim leading to different remedies. ${ }^{38}$ Nevertheless there is a tension between the two regimes. The remedial contractual regime is continuous with the contract, giving effect to the contractual allocation of risk, but the unjust enrichment regime creates a striking discontinuity. ${ }^{39}$ It gives effect to a different allocation of risk altogether. It is, in effect, this allocation of risk, not the contractual allocation of risk, that applies insofar as it favours the claimant. In circumstances where a breach or breakdown is in prospect it may be unpredictable which allocation of risk will apply. It seems that the contract, which was drafted to allocate risk, fails to do so. On this analysis, the availability of the restitutionary remedies undermines the freedom of the parties to determine the terms of their exchange in accordance with the contractual principle. If this is justifiable, it is in order to give effect to an independent principle of liability, the principle of unjust enrichment, just as, one might say, the operation of the law of tort in a contractual situation could have the effect of altering the allocation of risk. ${ }^{40}$ Whether it is justifiable depends on what the principle of unjust enrichment is. As discussed above, however, it is not at all clear whether there is such a principle or what it is.

\footnotetext{
38 See e.g. Burrows, above n8, 328-9; Beatson, above n37, 144; Treitel, above n8, 22-001; G Virgo \& J Beatson, "Contract, unjust enrichment and unconscionability" (2002) 118 LQR 352. Others deny that the unjust enrichment claim should arise only after termination: see e.g. Baloch, above n2, 139. There is an argument for general concurrence analogous to the position for contract and tort in SA Smith, "Concurrent liability in contract and unjust enrichment: the fundamental breach requirement" (1999) 115 LQR 245.

39 See Fried, above n28, 112-3, 131-2.

40 According to Lord Goff in Pan Ocean Shipping Co Ltd v Creditcorp Ltd [1994] 1 All ER 470, 475, "Serious difficulties arise if the law seeks to expand the law of restitution to redistribute risks for which provision has been made under an applicable contract". On the face of it, the availability of a restitutionary remedy does always have this effect.
} 
It might be suggested that the principle of unjust enrichment is a remedial principle that can supplement contract law by providing a remedy for the nonperformance of a contract where contract law cannot. ${ }^{41}$ The suggestion might be that in some circumstances, although the non-performance of the contract involves a contractual injustice, contract law is incapable of remedying it with the remedies that it has at its disposal, so the law of unjust enrichment comes to the rescue by providing an appropriate remedy. But this is to concede that the claim is actually contractual, however it may be described, and if the claim is contractual there can certainly be no justification for a remedy that is at odds with the contractual allocation of risk. If the claim for a restitutionary remedy is justifiable, it must be on the basis of a non-contractual principle of liability, though, it seems, a principle of liability that in some way depends or draws on the contract. As Stevens says: ${ }^{42}$ "The claim is based upon unjust enrichment, although its availability is determined by the construction of the contract."

The discussion in this section shows that there are problems with both the contractual and unjust enrichment analyses of the claim for a restitutionary remedy in the contractual context. The problem with the contractual analysis is that, under the standard analysis of contract in terms of an exchange of promises that generate duties of performance, there is no contractual injustice for which a restitutionary remedy can be the appropriate remedy. On the unjust enrichment approach, the defendant's failure to perform the contract creates an injustice not because it is a breach of duty in contract, but because it results in an unjust enrichment according to the principle of unjust enrichment. The problem is to identify the nature of the injustice in question, that is to say the principle of liability as it applies in this context. The unjust enrichment approach also needs to show how, if the claim is not contractual, the contract can nevertheless be relevant, since the claim does surely depend on the contract in some way.

\footnotetext{
41 For an approach along these lines see D Friedmann "The Protection of Entitlements via the Law of Restitution - Expectancies and Privacy" (2005) 121 LQR 400.

42 Stevens, above n20, 29.
} 


\section{The argument for an unjust enrichment claim}

The crucial issue is to establish the nature of the injustice that a restitutionary remedy in the contractual context corrects. This is now generally taken to be not a contractual injustice but an unjust enrichment, which is to say that the relevant principle of liability is the principle of unjust enrichment. What is required is to specify the principle of unjust enrichment and how it operates or what form it takes in the contractual context. When the nature of the injustice is specified, it is generally said to be the conditional character or "conditionality" of the contract, or "failure of condition" or "failure of basis", as the ground for the claim. ${ }^{43}$ I will refer to this as the conditional transfer theory. There seem to be various versions or interpretations of the conditional transfer theory, as I will consider in this section.

According to Burrows, the conditional transfer theory should be understood as follows. If the claimant, C, performs and the defendant, D, does not, $D$ is unjustly enriched, having had the benefit of C's performance without having reciprocated. The enrichment is unjust - there is an unjust factor because $^{44}$

"... the basis for the claimant's conferral of the benefit has been undermined or, put another way, the condition upon which the benefit was conferred has not been satisfied."

\footnotetext{
43 This is taken to be the correct interpretation of the traditional expression "failure of consideration": see e.g., Burrows, above n8, 319, relying on Fibrosa Spolka Akcjna v Fairburn Lawson Combe Barbour Ltd [1943] AC 32, and following Birks, above n15, 219. I do not discuss whether this is consistent with the traditional treatment of failure of consideration, nor do I discuss the relationship between the concept of failure of consideration and the concept of consideration in contract, or the controversy over "absence of consideration" as distinct from failure of consideration. My concern is with whether the idea of failure of basis or failure of condition can explain the availability of restitutionary remedies in the contractual context.

44 Burrows, above n8,319, drawing on Birks, above n16, 219, who described the benefit as qualified. Cf Beatson, above n37, who describes it as conditional, or qualified, or defeasible. For money and goods, it is at least possible for the transfer to be reversed by returning them, but for services one can only impose a liability to pay for them, which is an exchange rather than a reversal: see above $n 9$.
} 
I understand this to be the standard account of the conditional transfer theory.

The problem with it is that, although it is invoked to account for the restitutionary remedy on the assumption of the standard analysis of contract, it is incompatible with the standard analysis. A contracting party performs on the basis of the contract - the purpose of making the contract is to provide an agreed basis for performance - and, under the standard analysis of contract, this means on the basis that the other party has a reciprocal duty to perform. One might describe D's non-performance as a failure of the condition or basis on which $\mathrm{C}$ performed, but under the standard analysis the only appropriate remedy for the nonperformance is specific performance or expectation damages to correct the breach of duty, as discussed above. One might respond that, indeed, a restitutionary remedy is not an appropriate contractual remedy for nonperformance, but it is an appropriate remedy as a matter of unjust enrichment. But, if so, the reason for allowing the remedy remains obscure, because the basis or condition on which performance was provided was D's duty of performance under the contract, for which the contractual remedy for breach is appropriate and sufficient.

Of course, it is always open to the contracting parties $C$ and $D$ to agree expressly or impliedly in the contract that, if $D$ does not perform in accordance with the contract, $\mathrm{C}$ is to have a restitutionary remedy. This would achieve the effect of the conditional transfer theory through a contractual provision. The parties would indeed then have contracted on this basis. Such a claim would of course be purely a matter of contract. However, no such term is relied on for the conditional transfer theory, according to which the claim is non-contractual. ${ }^{45}$ It appears that, according to the conditional transfer theory, the principle of unjust enrichment achieves, in conjunction with the terms of the contract, the same effect as having such a term in the contract, but in the absence of any such term.

\footnotetext{
${ }^{45}$ Furthermore, under the standard analysis it would make no sense to say that there is an implied or default term providing for a restitutionary remedy to be available on termination. Any such term would be inconsistent with the express terms of the contract or with what is implied by them under the standard analysis. In any case, again any such claim would be contractual.
} 
Although the theory seems to be widely assumed, it is very difficult to see how this can be the case.

The usual view seems to be that the problem is avoided because the condition or basis does not arise from the contract, but outside and independently of it. It is said that support for this comes from the fact that, in the absence of a contract, it is possible for someone to confer a benefit subject to a condition, to the effect that the recipient is liable to return it or pay for it if the condition is not satisfied. For example, it is said that a gift made to someone on the basis that he is about to get married is recoverable if the marriage does not go ahead, because the gift was made on a condition or basis that failed, though there was no contract. ${ }^{46}$ But it is surely clear that, whatever the position in the absence of a contract, when there is a contract governing the provision of a benefit, performance is rendered exclusively on the basis of the contract, and any condition on which a contracting party rendered or purported to render his contractual performance, if it is not incorporated into the contract, is displaced by it, and cannot persist in parallel. One cannot perform on two different and inconsistent bases at the same time. Even if failure of basis or condition is the ground for a restitutionary remedy outside contract, it cannot be the ground for a non-contractual claim arising out of the non-performance of a valid contract.

In the case of a void contract that has been partly performed, it seems right that a contracting party should be entitled to have it unwound and performance returned or paid for by way of a claim for a restitutionary remedy. Such a claim is clearly not contractual, and it is now regarded as an unjust enrichment claim. It is sometimes said that in the case of the void contract the claim arises, just as for a valid contract, from the fact that the contract was not

\footnotetext{
46 Burrows, above n8, 320-1. See also Virgo, above n8, 307. It appears that in this type of case the claim arises only if $C$ has conveyed to $D$ that he intends to be paid and $D$ has accepted this, which suggests that the claim is based on an agreement, though one that for lack of certainty or consideration or for some other reason is not recognised as a contract. If this is so, then a fortiori there is basis for a distinct claim.
} 
performed, which is again said to be a failure of basis or condition. ${ }^{47}$ It seems curious that in the case of a void contract the claim should arise from nonperformance, ${ }^{48}$ and it does not make it any easier to see what is meant by failure of basis or condition. It surely cannot arise from what was agreed or ostensibly agreed in the void contract. It makes far more sense to think that in the case of a void contract it is the voidness of the contract or a mistake as to its voidness that gives rise to the claim, and this cannot of course be the basis for the claim in the case of a valid contract. The position for void contracts does not provide any support for a non-contractual, unjust enrichment account of the claim arising from the non-performance of a valid contract.

It is thought to be an advantage of the theory of unjust enrichment, and in particular the conditional transfer theory, that it provides a single, uniform explanation for restitutionary remedies applicable to valid contracts, void and voidable contracts, and also so-called "pre-contractual" and analogous cases, where the claimant does work during contractual negotiations that never come to fruition, or where the parties otherwise have dealings that do not amount to a contract. ${ }^{49}$ In all these cases, it is thought, the restitutionary remedy is justified on the ground that $C$ has conferred a benefit on $D$ on a basis or condition that fails, irrespective of whether or not there is a valid contract. But no account of failure of basis or condition has been presented that renders it irrelevant whether the benefit was conferred under a valid contract. As I have said, in the case of a valid contract the claim must depend on the fact that there was a valid contract that was not performed. The apparent advantage of the unjust enrichment approach arises from the misconception that if two claims are for the same or a

\footnotetext{
47 Burrows, above n8, 319-21.

48 In fact, the courts do not seem to have taken this position, as Burrows points out, above n8, 320.

49 And even, according to some, cases that have nothing to do with contract at all, like a claim to recover a mistaken payment. See e.g. Baloch, above n2, 179-80.
} 
similar remedy they must have the same basis and should be treated under the same doctrinal category. ${ }^{50}$

Consider the following, quite different version of the conditional transfer theory. A contractual provision whose breach justifies termination is described as a "condition" or "conditional term", ${ }^{51}$ reflecting the fact that, if the provision is breached, the other party is released from further performance. This usage might be taken to imply that a breach of contract by the defendant, $D$, not only releases the claimant, C, from further performance but also, as it were, retrospectively renders the contract void and frees him from the performance he has already rendered, so that he should be able to recover his performance by way of a restitutionary remedy. As Fried argues: ${ }^{52}$

"If your promise is conditional, then unless the condition is met you are under no obligation. When the condition fails, the promisee has no obligation to enforce - he cannot, for instance, enforce your obligation, proposing to deduct whatever damage you have suffered. There just is no obligation. It is gone. And if the person with a conditional obligation happened to make prepayment, then the principles discussed above would allow him to obtain restitution of that prepayment, since that prepayment was given pursuant to an obligation that no longer exists."

On this version of the conditional transfer theory, it seems that a terminated contract should be treated as if it were void, and it is the voidness of the contract rather than its non-performance that justifies the claim for restitution. However, this cannot be reconciled with the fact that the termination of a valid contract does not in fact render the contract void from the start. It is now understood that

\footnotetext{
50 In any case, the remedies should in principle differ significantly, in particular with respect to the relevance of the contractual valuation.

51 See Treitel, above n8, 2-103, 18-039. For discussion of contractual conditions in the present context, see for example Baloch, above n2, ch 6; Fried, above n28, ch 8.

52 Fried, above n28, 121.
} 
a valid contract that has been terminated is not equivalent to a contract that was always void or a contract that was voidable and has been rescinded. After termination, the contract, including the contractual allocation of risk, continues to apply with respect to remedial matters. ${ }^{53}$ The significance of the condition is only that $\mathrm{C}$ can terminate and the effect of termination is prospective only. It does not mean that the performance $C$ has already rendered is conditional in the sense of the conditional transfer theory. If on termination there is a claim for restitution of a payment made under the contract, it is not because the payment should be treated as never having been due, and if payment can be recovered for work done under the contract, it is not because the work should be treated as not having been due or rendered pursuant to the contract.

In contract law usage, "condition" or "conditional term" in the above sense is to be contrasted with "condition precedent". ${ }^{54}$ Sometimes a contract provides that a party can be liable for non-performance only once a condition precedent specified in the contract has been fulfilled, and the condition can be the other party's contractual performance. The purpose of such a provision is to lay down an order for the parties' performance, to assign the risk of having to perform first. If a contract provides that A's performance is conditional on B's, it would be natural to interpret it in this way as providing that $B$ is due to perform first, so $A$ cannot be liable for non-performance until B has performed. On this interpretation, the provision has no bearing on the availability of a restitutionary remedy. Alternatively, it might be interpreted as providing that, if $A$ performs and then $B$ does not, A can recover his performance or its value; this would be the contractual equivalent of the conditional transfer theory, and the claim would be,

\footnotetext{
53 Anson, above $\mathrm{n} 8,524$. It is said that at one time contractual duties were independent, in the sense that each party's duty persisted unaffected by a breach by the other party, so that if D breached C could not withdraw but would have to continue to perform whilst suing $D$ for breach. The modern position is that contractual duties are dependent, or conditional, meaning that $C$ can withdraw if the breach is of a conditional term or amounts to a repudiation, and it seems to be inferred by some that the move from independent to dependent contractual duties introduced the conditional transfer theory into the law: see Baloch, above n2, ch 5; see also Fried, above n28, 117, referring to PS Atiyah, The Rise and Fall of Freedom of Contract (Clarendon Press, 1979), 208-216. But contractual duties can be dependent in the sense that $C$ is entitled to withdraw only with prospective effect, and not with retrospective effect as the conditional transfer theory requires.

54 Treitel, above n8, 18-040, uses "condition" in this sense, by contrast with "condition precedent".
} 
in effect, a claim for a restitutionary remedy, though it would be an ordinary contractual claim, not an unjust enrichment claim. There may be a danger of conflating the two interpretations, and inferring that a claim for a restitutionary remedy arises by virtue of a provision that was actually intended to lay down an order of performance. ${ }^{55}$ In any case, there is no room for saying that there can be a condition in the contract that makes A's performance conditional on B's, and in some way generates a claim to a restitutionary remedy in the event that $A$ performs and B does not, unless this is the contractual effect of the condition and the claim is contractual.

The conditional transfer theory should be distinguished from the following type of case, arising from a condition precedent in the contract. ${ }^{56}$ Say B's liability to pay arises only once A has provided goods or services under the contract, but for some reason $B$ pays before $A$ has performed. B may then have a claim to recover his payment (though presumably he would not normally pursue it unless the contract breaks down). Such a claim would not be a contractual claim, though whether it arises depends, in part, on the construction of the contract. The basis for the claim does not appear to be that the payment was made conditionally, however. If B has a claim it is surely because when he made the payment he was not yet liable to pay and A did not yet have an accrued right to be paid, or B mistakenly thought that he was liable to pay and that $A$ had an accrued right to be paid. In any case, consideration of this type of case does not provide any support for the conditional transfer theory, or explain the general availability of a restitutionary remedy. It does not show that a claim for a restitutionary remedy arises in an ordinary case where A is due to perform first and does so and then B fails to perform, including an ordinary example of total failure of consideration. ${ }^{57}$

\footnotetext{
55 See the criticism of Baloch's approach in C Webb, "Unjust Enrichment and Contract" (2010) 126 LQR 337, 341-2.

56 See Stevens, above n20, 24-30.

57 See Webb, above n55, 341.
} 
Fried develops what appears to be a distinct version of the conditional transfer theory to explain restitutionary remedies in the contractual context. He considers a case where the claimant, $\mathrm{C}$, has paid in advance for a product that is now worthless and the defendant, D, declines to perform. C's expectation measure is nil, and D has saved himself the cost of performing. Fried considers why it is that $C$ should be entitled to recover the payment made in advance. He points out that a contractual regime ${ }^{58}$

"... must maintain the integrity of bargains, and this means not reversing the allocation of risks on which the parties evaluated their bargain when they made them. Bargains are struck and their prices are evaluated on the assumption that they will be kept... Contractual parties do not imagine that they will have to pay for performances that they do not receive."

Fried's point is that $C$ contracts on the assumption that $D$ will actually perform, not merely that he, $\mathrm{C}$, will receive the value of performance. The fact that $\mathrm{C}$ receives the value of performance in the form of expectation damages is not enough if $D$ has been relieved of the burden of performance. In other words, $C$ contracted on the basis that $\mathrm{D}$ accepted a duty to perform, and contract law should not allow D, when it suits him, not to perform his duty, and instead merely pay damages (if any), and walk away with a profit in the form of his saved costs of performance. The law would not then treat $D$ as genuinely subject to a duty to perform in accordance with his promise. This would be inconsistent with the terms of the contract and the allocation of risk implicit in it, in the light of the standard analysis.

According to Fried, the implication is that a principle of unjust enrichment should operate to give $\mathrm{C}$ a restitutionary remedy to recover the value of his performance. But it is not clear how this possibility enters the picture. The

58 Fried, above n28, 117 
argument appears to show that the remedial regime in contract is defective in failing to provide, as a general rule, for specific performance to compel the defendant actually to perform. The absence of specific performance means that the law does not properly give effect to or vindicate the primary relation, and this subverts the contractual allocation of risk, even if $C$ receives the full value of the performance due to him through expectation damages. The availability of specific performance would directly answer C's complaint. This is surely how the problem ought to be addressed under the standard analysis. Failing this, one might say that $D$ should be required to disgorge his wrongful profit - his savings from his breach of duty. This would at least impose on $D$ the cost of the performance that he had a duty to provide, and to this extent enforce the contractual allocation of risk. As mentioned above, ${ }^{59}$ the disgorgement of wrongful profits is not the same thing as a restitutionary remedy. Disgorgement removes the profit of wrongdoing, based on the principle that a wrongdoer should not be allowed to profit through a wrong, whereas a restitutionary remedy involves returning the claimant's payment to him or paying him for work done or a benefit conferred. Fried's argument does not justify a restitutionary remedy, which, on the standard analysis of contract, is liable to subvert the contractual allocation of risk rather than enforcing it. However, it does suggest that there is something amiss in the remedial regime under the standard analysis of contract - there seems to be a problem arising from the fact that the remedial regime does not properly vindicate the primary relation, and so fails to give effect to the allocation of risk, according to the standard analysis - or alternatively that there is a problem with the standard analysis.

In my view, no plausible account is available of the claim for a restitutionary remedy in the contractual context as an unjust enrichment claim, that is to say, as a claim based on a non-contractual principle of liability that might support a doctrinal category of unjust enrichment. In particular, none of the

\footnotetext{
59 See above at $n 11$.
} 
variants of the conditional transfer theory provide an account of any such principle. The conditional transfer theory relies on the fact that the claim arises from the divergence of the parties' actions or other events from what was specified in the contract, irrespective of whether this divergence can be characterised as a breach of duty. In fact, the claim is a contractual claim, arising to remedy a contractual injustice, and the problem in explaining it lies in the standard analysis of contract, which wrongly treats all contractual claims as arising from the breach of a duty to perform the contract.

\section{A contractual analysis of restitutionary remedies in the contractual context}

A suggested contractual approach to the restitutionary remedies

The problem with the contractual analysis of restitutionary remedies is that a restitutionary remedy cannot be understood as an appropriate response to the non-performance of a contract under the standard analysis, because a restitutionary remedy does not rectify the breach of a contractual duty to perform: only expectation damages or specific performance can do this. Is there any way around this objection? Is there a different way of understanding contract that, unlike the standard analysis, can support a primary relation that is vindicated by the restitutionary remedies?

The function of contractual agreement is to facilitate exchange. The problem for parties who want to make an exchange for mutual benefit, in the absence of agreement, is that there is a risk that they will provide goods or services without being paid for them, or make a payment in advance for goods or services without receiving them. Insofar as it is likely to be respected or enforced, an agreement, understood in accordance with the standard analysis as an exchange of promises that generate duties of performance, provides reassurance to the parties that they can proceed by giving them an entitlement to receive the performance due to them under the contract. 
However, it is possible to have a different form of agreement to facilitate exchange, which establishes a different basis for performing. As the agreement is understood on this alternative approach, although the purpose of the parties in making the agreement is to make the exchange, and each party generally intends to carry it out and expects the other to do so, the agreement does not involve promises to carry it out, and it does not create a duty to perform or a right to receive performance from the other party. ${ }^{60}$ The reassurance that the agreement provides is not a right to performance in the sense of a right correlated with a duty to perform on the part of the other party. In the case of a contracting party who supplies goods or services under the contract, one can conceive of the contract as generating a right to a return for him in respect of what he has done, the measure of which increases as he performs. This is his contractual interest. In the usual case, where the contract is performed, the contractual interest is satisfied by payment from the other party. But if the contract terminates early, the contractual interest can be satisfied by a pecuniary remedy, the fundamental measure of which is not the value to the claimant of the performance he would have received if the contract had been completed, as under the standard analysis, but an appropriate return in accordance with the contract for what he has done, i.e., a quantum meruit. The effect of the agreement on this understanding is to transfer to the other contracting party the risk that what a contracting party has done under the contract will be wasted by the failure of the other party to perform, though without imposing a duty of performance. This is the reassurance that contract law provides to potential contractors. For a contracting party who has paid in advance for goods or services, the satisfaction of the contractual

\footnotetext{
60 See n12 above. See also P Jaffey "Damages and the Protection of Contractual Reliance", in R Cunnington \& D Saidov, Contract Damages: Domestic and International Perspectives (Hart, 2008), 139. It is not uncommon to find arguments that the law does not really treat breach of contract as wrongful: see for example S Shiffrin, "The Divergence of Contract and Promise" 120 Harvard Law Review 708, 723-5 (2007). Sometimes such arguments also deny that the agreement involves promises of performance as normally understood: some recent examples include $\mathrm{R}$ Craswell, "Promises and Prices" 45 Suffolk University Law Review 735 (2012); G Klass, "Promise Etc" 45 Suffolk University Law Review 695 (2012).
} 
interest requires the return of the payment, except insofar as the contractual interest has been satisfied by contractual performance from the other party.

One might describe this contractual interest as a contractual reliance interest, meaning the interest in a return on the investment of labour and other resources in reliance on the contract, including compensation for reliance loss. This is a natural way to understand the interest that contract law protects, because it reflects the role of contract law in enabling people to secure a return by exploiting their labour and resources. It is not, however, what is usually described as the reliance interest in contract, which is confined to the interest in compensation for reliance loss. ${ }^{61}$

This approach can in principle explain the restitutionary remedies as contractual remedies. ${ }^{62}$ It explains them as contractual remedies in the same way as contractual remedies are normally explained, as remedies that are apt to vindicate primary rights in contract. In my view, insofar as a claim for a restitutionary remedy can arise out of a valid contract, this is the way to explain it. If it is right to understand a contractual agreement in this way, it is, in the end, because this is the form of agreement that the contracting parties actually made, or are presumed to have made. I will come back to this point below.

Because he has not promised to perform, and has not incurred a duty to perform, under the suggested approach a contracting party is free to withdraw if he now thinks that this is in his best interests, subject to satisfying the other party's contractual reliance interest, and when a contracting party is said to commit a breach of contract, this means departing from the envisaged performance, but it does not ordinarily involve the breach of a duty to perform. Under the suggested approach, it is more apt to say that a contracting party's primary right is correlated not with a primary duty of performance but with the

\footnotetext{
61 Nor is it the same as the "restitution interest", as this is normally understood, which is understood as a measure of benefit received by the defendant. The concept of "interests" in this sense is of course associated with Fuller \& Perdue, above n33.

62 Though on this understanding, "restitutionary remedy" may be an inapt expression for the quantum meruit.
} 
other party's "primary liability", signifying the potential to generate a remedial liability in the event of non-performance. ${ }^{63}$ It is this non-performance, or more broadly departure from the specified terms of the exchange, that is referred to as a "failure of condition" or "failure of basis", but on the suggested approach its significance is entirely contractual. ${ }^{64}$ For convenience, I will continue to use the expression "breach", to be understood in this way.

On this approach, restitutionary remedies are explicable as remedies in contract, but what about the ordinary contractual remedies of expectation damages and specific performance? These are usually understood as enforcing the parties' duty to perform, and on this understanding they are explicable only under the standard analysis. There is, of course, nothing to be said for an understanding of contract that can explain the restitutionary remedies but not these ordinary contractual remedies. What is required is an understanding of contract that can explain all the various remedies that may be available, as a coherent set of remedies, each being the appropriate remedy to vindicate the agreement in the particular circumstances in which that remedy is available. Thus I will consider first whether, focussing on matters of principle, the suggested understanding of an agreement can provide a satisfactory account of the overall remedial regime in contract, including the restitutionary remedies, in particular by comparison with the standard analysis of contract combined with the unjust enrichment approach for restitutionary remedies. If this is the case, as I suggest, then the suggested approach at least deserves consideration as a possible account of restitutionary remedies in contract. One might object that the suggested account cannot be correct, however successful it might be in accounting for the remedial regime in contract, because it simply

\footnotetext{
63 See Jaffey, above n14, ch 1. K Barker, Review Article, [2001] RLR 232, 234 and Baloch, above n2, 66 , both question how non-performance or failure of performance can be legally significant other than as a breach of duty. See also D Sheehan, "The Property Principle and the Structure of Unjust Enrichment" [2011] RLR 138.

64 On the suggested approach, this can extend to the failure of a state of affairs assumed in the contract, as in Roxborough v Rothmans of Pall Mall Australia Ltd (2001) 208 CLR 516, which cannot plausibly be treated as a breach of duty under the standard analysis.
} 
mischaracterises a contract by denying its basis in promises of performance. I will come back to this point below.

\section{The quantum meruit and the expectation measure}

Expectation damages are taken to be based on the defendant's contractual duty of performance, but under the suggested approach, where the claimant has performed by providing goods or services under the contract, his fundamental entitlement is to the protection of his contractual reliance interest by way of a quantum meruit. However, confining the claimant to a quantum meruit is in practice liable to undercompensate, in the sense of failing to satisfy the contractual reliance interest, and awarding the expectation measure as a general rule is justified to avoid this risk of undercompensation.

Under the suggested approach, a contracting party implicitly accepts that his contractual interest in respect of his performance of the whole of his side of the contract would be satisfied by the receipt of all the benefit due to him under the contract. This equation is the contractual valuation. In the light of the contractual valuation, one would expect the quantum meruit to be measured pro rata, as a proportion of the payment due for full performance. On the suggested approach, it would appear that the law should give proportionate effect to the contract when it breaks down, whereas under the standard analysis the law should put the claimant in the position he would have been in if the contract had been completed. In reality, however, to give proportionate effect to the contract will usually if not invariably be impracticable. As Anson points out, there may be problems in allocating a particular proportion of the contract price to a particular part of the contractual performance due from the claimant. One reason is that the claimant's costs may include fixed costs incurred at the start; another is that there may be economies of scale that would be obtainable from full performance 
but are not realised from part performance. ${ }^{65}$ The implication, in my view, ${ }^{66}$ is that the expectation measure rather than the pro rata measure should be allowed, as a safer if potentially overgenerous measure of what is necessary to protect the contractual reliance interest, in accordance with the contractual valuation.

The effect of the contractual valuation is that the claimant will not generally be entitled to a quantum meruit in excess of the expectation measure. ${ }^{67}$ Some supporters of the unjust enrichment approach deny that the contractual valuation should apply to the quantum meruit, and consider that the market rate for the claimant's time and materials should apply instead. Thus they hold that it may be appropriate, if the market rate has gone up since the contract was made, for the quantum meruit to exceed the expectation measure, allowing the claimant to escape from a bad bargain by way of an unjust enrichment claim to a restitutionary remedy. ${ }^{68}$ If the claim for a quantum meruit is non-contractual, it does indeed seem very difficult to see why the contractual valuation should apply. If a quantum meruit is awarded for work done under a void contract, it seems clear that in principle the contractual valuation should not apply.

Other supporters of the unjust enrichment approach argue that, even if the claim for a quantum meruit is a non-contractual, unjust enrichment claim, it would be unfair - absurd even - if the contractual valuation did not apply and a contracting party who has made a bad bargain could escape from the contractual valuation. ${ }^{69}$ One view is that the contractual valuation provides evidence of the value placed on the benefit by the parties, and this is relevant to the measure of a non-contractual quantum meruit. ${ }^{70}$ However, the effect of the contractual valuation is not just to adopt the parties' judgement of the value of the benefit

\footnotetext{
65 See Anson, above n8, 595-6.

66 The argument in Anson is that these considerations support disapplying the contractual valuation. 67 If $D$ breaches and $C$ has a losing contract he may be able to claim more through a quantum meruit than the expectation measure, consistently with the contractual valuation, because the measure need not take account of some of the expenses $C$ would have incurred if the contract had been completed. 68 e.g., Fried, above n28, 114; Burrows, above n8, 341, 349. Anson gives reasons why the contractual valuation should not apply, which seem really to be reasons why the expectation measure should be used: see above n66.

69 See Treitel, above n8, 22-022.

70 Burrows, above n8, 349-50
} 
provided, but to allocate the risk of changes in the costs and benefits of contractual performance, and it is difficult to see how this can be justified if the claim is not contractual. It seems to me that commentators who insist that the contractual valuation should apply are really committed to a contractual approach along the lines of the suggested approach, rather than an unjust enrichment approach combined with the standard analysis.

On the suggested approach, the quantum meruit is a measure of what is necessary to satisfy the contractual reliance interest. It does not depend on a benefit having been conferred on the defendant. Reliance damages in respect of loss, including expenditure, incurred in performing the contract should be understood, on the suggested approach, not as a proxy for, or a species of, expectation damages, but as a variant or component of the quantum meruit. If the pro rata measure or the expectation measure is difficult to establish, it seems reasonable to say that the claimant should be able to recover a quantum meruit assessed in terms of a market rate, but subject to the expectation measure cap if the defendant can establish it. This position is established for reliance damages, as mentioned earlier. The usual view is that the expectation cap is appropriate for reliance damages only because reliance damages are a proxy for, or a species of, expectation damages, as Baloch points out, ${ }^{71}$ but on the suggested approach the cap is justified because the quantum meruit in respect of work done and expenditure is subject to the contractual valuation. The quantum meruit is not a measure of actual loss incurred, but of the appropriate payment in respect of contractual part performance, including expenditure, measured according to the contractual valuation, to reflect the way in which the contract valued the claimant's performance.

The expectation measure more generally

\footnotetext{
71 Baloch, above n2, 67.
} 
This argument extends to reliance loss incurred by the claimant in giving up other possible opportunities in order to enter into the contract, i.e. the opportunity cost of making the contract. This type of reliance loss is incidental to performance rather than being incurred through performance, ${ }^{72}$ but it seems clear that if the law is to facilitate contractual exchange under the suggested approach the other party should be responsible for this type of loss if he does not perform. Because the opportunities forgone might well have provided the contracting party with the same or a similar benefit to the benefit he is contracting to obtain, or another benefit of similar value, and the actual measure of the loss may be difficult to determine directly, the claimant should be protected by allowing the expectation measure, which is normally easier to determine. Again, it is true that the expectation measure is liable to overcompensate in many cases, but it seems reasonable nevertheless, on the basis that, although he does not act wrongfully, the defendant should bear the risk of the evidential problems involved when he is responsible for the breakdown of the contract. ${ }^{73}$ Conversely, as for reliance damages, the expectation measure should also be a cap on recovery, in accordance with the contractual valuation. By contracting the defendant took responsibility for such reliance loss, but only in accordance with the contractual valuation, which is to say only up to the value of the benefit the claimant would have obtained through the contract. The claimant should bear the risk of incurring reliance loss in excess of this amount.

Thus, although the suggested approach does not recognise the right to the expectation measure as the fundamental entitlement of a contracting party in the way that the standard analysis of contract does, it does nevertheless support it as the usual remedy.

\section{The recovery of prepayments}

\footnotetext{
72 This is the distinction made by Fuller \& Perdue, above $n 33,78$, between essential and incidental reliance loss.

73 The opportunity cost argument is derived from Fuller \& Perdue, above n33.
} 
Under the standard analysis of contract, the claimant has only a right to the performance due to him under the contract, and there is no contractual basis for a claim to recover a payment made in advance unless the remedy can be understood as a proxy for the expectation measure, and on this basis the recovery should be capped at the expectation measure. Thus, as discussed above, the fact that the recovery of a prepayment is not capped is taken to imply that the claim is a non-contractual, unjust enrichment claim. ${ }^{74}$ It also means that the recovery of prepayments is the most important type of case in which a restitutionary remedy is liable to be preferable to the expectation measure.

However, under the suggested approach there is a contractual claim to recover a prepayment, to satisfy the contractual reliance interest. Furthermore, even though the claim is contractual, the measure of recovery should not normally be capped at the expectation measure. The contractual valuation is normally concerned with determining the measure of recovery in respect of work done and expenses or other losses incurred in reliance on the contract, and so it should not normally apply to the recovery of prepayments. For example, if $C$ is buying goods in an ordinary contract of sale and pays in advance, he should get the full payment back if he does not receive the goods from $D$, even if the goods are now worth less on the market. In this type of case, the provision for C to pay in advance is to provide a form of security for payment to $D$, to save $D$ from having to take action to recover payment after he has performed. It is not intended to allocate the risk of change in the price of the goods so as to justify limiting $C$ to the recovery of the expectation measure if the price falls after the payment is made. But in some cases where $\mathrm{C}$ has made a prepayment, he may be rightly confined to the expectation measure; for example, if $C$ and $D$ make a futures contract relating to goods, in effect a contract of speculation over the future price of the goods, it is in the nature of the contract that, having made his

\footnotetext{
74 Burrows, above n8, 344-5.
} 
prepayment, C's interest is only in the price of the goods, and in principle he should be able to recover only the expectation measure. ${ }^{75}$

What about where $C$ has paid in advance and $D$ has part performed? On the suggested approach, D's part performance should reduce C's measure of recovery if $\mathrm{C}$ has received a contractual benefit from it. ${ }^{76}$ The relevance of the benefit is that it goes to satisfying C's contractual reliance interest in part, and the benefit would usually be measured as the reduction in the cost of making up the contractual benefit from elsewhere. ${ }^{77}$ It is entirely a contractual matter, in accordance with the suggested approach, and there is no need to invoke a principle of unjust enrichment to explain it.

The traditional position is that $\mathrm{C}$ has a claim to recover a prepayment only where there has been a total failure of consideration, i.e., where $D$ has not performed at all. This condition has long been criticised as an arbitrary limitation on the recovery of a prepayment, but has not yet been abandoned, ${ }^{78}$ though the law is said to be "on the turn". ${ }^{79}$ The rationale for the condition is understood to be the difficulty involved in measuring the benefit received by $C$ when $D$ has provided only a part of his performance. ${ }^{80}$ This seems open to objection on the ground that there is no reason why the difficulty should prejudice $C$, if $D$ was the party in breach. It would seem sufficient that C's recovery will be reduced insofar as $D$ can establish that $C$ received a benefit. However, possibly there are cases where because of the nature of the contract - the inherent difficulty of apportionment - the claimant should be understood to have accepted that by making the payment in advance he has confined himself to the expectation

\footnotetext{
75 See Treitel, above n8, 22-003.

76 Also, since D was the party in breach, there seems no reason why C's recovery should be reduced to give $\mathrm{D}$ a return on what he has done under the contract, in the form of a quantum meruit, where no benefit or no proportionate benefit from it has reached $C$.

77 Just as it would be in connection with the expectation measure, where the expectation measure is reduced because the cost of having the work completed is reduced.

78 The recent case of Guido van der Garde BV v Force India Formula One Team Ltd [2010] EWHC 2373 retains the total failure requirement with some reluctance.

79 Anson, above n8, 588.

80 And the payment is not capable of being apportioned to different parts of the goods or services supplied. See e.g., Burrows, above n8, 331; Anson, above n8, 588.
} 
measure, just as he does for different reasons in the example of the futures contract mentioned above. ${ }^{81}$

It is said that it is the increasing recognition of the unjust enrichment approach that that is behind the perception that the law needs to abandon the total failure requirement and allow the claim to recover a prepayment or a part of it to be generally available. ${ }^{82}$ On this understanding, allowing a claim to recover a prepayment, in whole or in part, involves allowing the law of unjust enrichment to override the law of contract. But the nature of the injustice in issue, and the relevant considerations in determining whether such a claim should be allowed, seem to be entirely contractual - they are to do with how the parties' agreement should be understood, how it allocated the risks of certain contingencies, and what remedy should be available given that the agreed exchange has not been completed.

\section{The "wrongdoer's claim"}

Here A makes a payment in advance or provides goods or services before payment and then himself breaches and makes a claim against $B$ for a restitutionary remedy. In some such cases a claim has been allowed. ${ }^{83}$ In the light of the standard analysis, it seems that if a claim is allowed it must be an unjust enrichment claim, because it is not based on the breach of a contractual duty by the defendant $B$, and it is not a claim for expectation damages to vindicate a contractual duty. It is said there is a conflict between contract law, which denies A a claim because no duty to pay under the contract has yet arisen, and unjust enrichment law, which does give A a claim. ${ }^{84}$

Again, however, it seems to me that if there is any injustice involved in denying $\mathrm{A}$ a claim it must be a contractual injustice, and the suggested approach

\footnotetext{
${ }^{81}$ See Treitel, above n8, 22-004.

82 Anson, above n8, 590.

83 Dies v British and International Mining and Finance Co [1939] 1 KB 724 allows a claim to recover a prepayment; Sumpter $v$ Hedges [1898] 1 QB 673 denies a claim for a quantum meruit, though the case is controversial.

84 Treitel, above n8, 22-023.
} 
shows how there can be such a contractual injustice. Each party has accepted responsibility for the other's contractual reliance interest and a claim under the contract does not depend on a breach of a duty to perform, but a shortfall in the satisfaction of this interest. It seems reasonable to say that, although B's contractual interest should be protected first, if B is left better off than if the contract had been performed - his contractual interest more than fully satisfied and A's contractual interest is unsatisfied, it should be satisfied out of B's surplus. ${ }^{85}$

\section{Frustration}

When a contract has been frustrated, the traditional position seems to have been that no claim in contract should arise because neither party has committed a breach of duty (although a claim to recover a prepayment on a total failure of consideration has always been available. ${ }^{86}$ ) It came to be accepted that it could be unfair to make each party bear the risk that the contract might terminate after he has performed but before he has received what he was due in return, and for a long time claims have been available under the Law Reform (Frustrated Contracts) Act 1943.

Some commentators argue that claims arising on frustration are in principle unjust enrichment claims ${ }^{87}$ but other writers have argued that they should be understood in terms of the sharing of losses. For example, Fried argues that, if a contingency arises in respect of which the contract has not allocated the risk, it is fair that the risk should be shared because the parties were involved in

\footnotetext{
${ }^{85}$ Where a contract provides for B to perform before A pays him, it is sometimes said to preclude a contractual claim in the event of termination before B completes, but it is not clear that such a provision, which seems really intended to assign the risk involved in performing first, should be understood in this way. See e.g. R Stevens and B McFarlane "In defence of Sumpter v Hedges" (2002) 118 LQR 569. It is sometimes said that to allow a claim for the wrongdoer, $A$, would remove his incentive to complete the contract, and so unfairly weaken the position of the other party, B, but it is doubtful whether this is the case if A's claim can only be satisfied out of B's surplus. See e.g. the dissenting note by Brian Davenport QC to Law Commission Report no 121 (1983) Law of Contract: Pecuniary Restitution on Breach of Contract. In any case, these are in principle purely contractual matters.

${ }^{86}$ Fibrosa Spolka Akcjna v Fairburn Lawson Combe Barbour Ltd [1943] AC 32.

87 See e.g. Burrows, above n8, 361.
} 
a common venture, and this is why a claim should arise on frustration. ${ }^{88}$ But, if so, what should the remedy be? The effect of frustration under the standard analysis is to deprive each party of his right to performance, and relieve each party of the duty to perform. It would seem that the solution should be for the parties to share losses relative to the position they would have been in if both had fulfilled their duties, i.e. the court should work out the aggregate expectation losses of the two parties and then require a payment from one to the other to equalise these losses. However, this is not what is understood or generally advocated by Fried or others as loss sharing. Generally loss sharing is taken to be concerned with losses incurred in performing the agreement, such as contractual expenditure and contractual payments.

Burrows rightly insists that loss sharing has to have a principled rationale. ${ }^{89}$ It cannot be based merely on the sense that it gives a fair outcome. In the absence of any such rationale, he argues, we should stick to the unjust enrichment approach. But, as I have said, it is the unjust enrichment approach that has failed to supply a principle of liability to show the basis in justice for the claim, and by contrast a form of loss sharing does have a sound basis in the suggested contractual approach. Under the suggested approach, there is no difficulty in saying that a contractual claim arises on frustration, because a contractual claim is not necessarily based on a breach of duty. Each party's responsibility for the other's contractual reliance interest should give the other party a prima facie claim, and overall there should be a transfer to equalise the shortfall. The prima facie claim is not for an expectation loss, nor simply for loss incurred through the performance of the agreement or in reliance on it. It is for a measure to cover contractual payments and work and expenses according to the contractual valuation, subject to a reduction for any benefit received pursuant to

\footnotetext{
88 Fried, above $\mathrm{n} 28$, ch 5 . Thus Fried does not treat this as an unjust enrichment claim. See also $\mathrm{E}$ McKendrick, "Frustration, Restitution, and Loss Apportionment" in Burrows, ed, Essays on the Law of Restitution (Clarendon Press, 1991); AM Haycroft \& DM Waksman, "Frustration and Restitution" [1984] JBL 207.

89 Burrows, above, n8, 366.
} 
the contract. In the context of frustration, there is no reason to use the expectation measure as a presumption to favour one party over the other. This seems to me the best solution, and also the most plausible basis for the provisions of the Act. ${ }^{90}$

The contractual account I have suggested above explains the availability of the restitutionary remedies, the quantum meruit and the recovery of a prepayment; it explains the contractual valuation and the expectation measure cap for the quantum meruit, and the absence of an expectation measure cap for the recovery of a prepayment; it explains why benefit to the defendant is not necessary for a restitutionary remedy, and the way in which benefit is relevant; and it explains the basis for claims on frustration and the "wrongdoer's claim". This account of the restitutionary remedies seems to me more comprehensive and more convincing than the unjust enrichment account. Furthermore, the suggested approach can explain the general availability of the expectation measure, and in addition, it can explain another fundamental feature of the remedial regime in contract, the non-availability, as a general rule, of specific performance.

\section{Specific performance and disgorgement}

The established rule is that specific performance is not available as a general rule but only where "damages are inadequate". ${ }^{91}$ The general availability of specific performance would be a dramatic change in the position of parties to a contract: it would secure for a contracting party the right to receive actual performance, which he would have to relinquish only on terms acceptable to him. If, as the standard analysis holds, the parties do normally have a right to receive

\footnotetext{
90 See further Jaffey, above $\mathrm{n} 12,66-75$. The Act is not consistent with the unjust enrichment approach because the protection it gives in respect of loss incurred cannot always be explained in terms of change of position as the unjust enrichment approach requires: see Burrows, above n8, 364. It is not consistent with the suggested approach because it fails to give a return on work done going beyond reliance loss, unless a benefit has been conferred. The proper approach would take account of performance in two ways, first protecting work done and secondly taking account of benefit conferred as satisfying in part the contractual interest of the other party.

91 See generally Treitel, above n8, 21-027.
} 
performance and a duty to perform, one would surely expect the contract to be enforceable by specific performance as a general rule, ${ }^{92}$ certainly in the ordinary case where performance is perfectly possible and no more burdensome than was envisaged when the agreement was made. It seems wrong that in these circumstances a contracting party should be allowed not to perform, subject only to a liability to pay damages. Under the standard analysis, this seems to be a failure of vindication, and a subversion of the contractual allocation of risk. This seems very clear by comparison with what would happen in the case of a duty not to enter property or cause damage or injury, for example. As discussed above, Fried argued that limiting the claimant to expectation damages subverts the contractual allocation of risk because the contract was made on the assumption that the defendant had a duty to perform, and would accordingly bear the burden of performance. Fried argued that this justifies a restitutionary remedy, but, as pointed out above, the solution under the standard analysis is for the contracting parties to have a right to specific performance as a matter of course, or, failing that, disgorgement to prevent the defendant from avoiding the cost of the performance he had a duty to provide.

The suggested approach explains the traditional position, because it holds that the parties do not ordinarily have a right to the performance of the contract or a duty to perform it. ${ }^{93} \mathrm{~A}$ contracting party has a right to the protection of his contractual reliance interest, and this is normally more than adequately satisfied by the expectation measure of compensation. However, when this is not the case, because the contractual benefit is unique and can be obtained only from the defendant D, D's responsibility for C's contractual interest should generate a duty

\footnotetext{
92 This seems to be the natural implication of the idea that contract law gives the expectation measure in order to protect the "performance interest" or "expectation interest": see above n-. A number of writers have taken the view that the standard analysis is problematic with respect to the non-availability of specific performance: see e.g. D Kimel, Promise to Contract (Hart, 2003).

93 It also deals more satisfactorily with contractual claims that are said to arise from the breach of a "strict liability duty" in respect of an event or state of affairs, and with the fact that in other respects non-performance of a contract does not appear to be treated as wrongful.
} 
to perform, which should be protected by specific performance. ${ }^{94}$ The suggested approach can thus explain the traditional "damages are inadequate" rule for specific performance. The function of the rule is not to determine whether in the particular circumstances a remedy of specific performance should be awarded to enforce the defendant's duty of performance (since if there is a duty of performance it should ordinarily be vindicated by specific performance), but whether in the particular circumstances the defendant actually had a duty to perform, so that specific performance to enforce it is the appropriate remedy. ${ }^{95}$

The suggested approach also explains the position for disgorgement. On the face of it, according to the standard analysis contractual non-performance is always wrongful (if the contract is in force), and so the profits of nonperformance should always be subject to disgorgement, if the principle of disgorgement of wrongful profits is to be applied consistently. Disgorgement is not generally available in contract, however; it now appears to be available according to broadly the same "damages are inadequate" test as for specific performance. ${ }^{96}$ The test should not be understood as identifying cases where the removal of the profits made by the defendant through a breach of duty is an appropriate substitute for compensation, because of the difficulty of measuring loss. This is not the function of disgorgement, which is to remove wrongful profits. The test should be understood, again, as determining whether the defendant's non-performance constituted a breach of duty, so that his profit was

\footnotetext{
94 This is particularly the case where the contractual benefit is necessary for the functioning of C's business so that $C$ has become dependent on D's actually performing to avoid serious loss, as in $S k y$ Petroleum v VIP Petroleum [1974] 1 WLR 576.

${ }^{95}$ It is said that to allow specific performance in general would undermine the mitigation rule, and of course if $C$ could always require $D$ to perform there would never be any reason for $C$ to take steps to mitigate loss resulting from D's non-performance: see e.g. Anson, above n8, 574. The two rules go together: they both reflect the absence of a duty to perform on the part of $D$. They are at odds with the standard analysis, and consistent with the suggested approach. If $D$ is free to withdraw from performance, as the general absence of specific performance implies, C must also be bound to accept the withdrawal and should not be able to recover for any further losses incurred by continuing to rely on the assumption that D will perform. See PS Atiyah, Essays on Contract (Clarendon Press, 1986), 124.

96 Attorney General v Blake [2000] 3 WLR 625. I leave aside the general objection to disgorgement that it should not be allowed in civil proceedings because it is not a remedy for $C$, in the sense of correcting, viz-a-viz C, the wrong or injustice that $C$ has suffered, so that it gives $C$ a windfall. Some argue that punitive damages should also sometimes be available for breach of contract and if so they would be available, like disgorgement, only when breach of contract is wrongful.
} 
wrongful. The test reflects the suggested approach, according to which a contracting party is generally free not to perform and so the profits made as a result are not wrongful profits, even if the contracting party acts deliberately to make a profit in this way. The profits are wrongful only where the defendant has a duty to perform because his performance is necessary to protect the claimant's contractual reliance interest.

Thus the suggested approach can explain not only the restitutionary remedies, but also what is really the most fundamental feature of the remedial regime in contract, the combination of the availability of the expectation measure and the non-availability of specific performance and disgorgement in the ordinary case.

\section{Which is the better theory of restitutionary remedies in the contractual context?}

Two accounts compared

The discussion above shows how a claim for a restitutionary remedy in the contractual context can be understood as a contractual claim rather than an unjust enrichment claim. On the suggested approach, the claim is contractual in the same way as an ordinary contractual claim for expectation damages or specific performance is contractual, which is to say that, in the particular circumstances in which it is available, the remedy vindicates the primary relation in contract, protecting and fulfilling the right created by the agreement and undoing the injustice arising from non-performance.

The alternative, now orthodox view is that a claim for a restitutionary remedy in the contractual context is a claim in unjust enrichment. It arises outside contract to supplement the ordinary contractual claims for expectation damages and specific performance. The most plausible argument for this view is that the claim for a restitutionary remedy cannot be contractual because, assuming the standard analysis, a restitutionary remedy is incapable of 
vindicating a primary right in contract. But even accepting this, the argument falls short as an argument for the unjust enrichment approach, because it does not identify an unjust enrichment principle of liability that can provide the basis for a claim. In my view, no plausible account of such a principle, or its operation in the contractual context, has been supplied. Indeed, the usual unjust enrichment analysis - the conditional transfer theory - seems to be that the parties should be held to the basis or condition on which they performed, and this appears to be essentially a matter of contract. The implication is that if the standard analysis of contract is right there is no basis for a restitutionary remedy, contractual or otherwise, and that if a restitutionary remedy ought to be available there is a problem with the standard analysis.

Baloch, who favours the unjust enrichment approach, rejects an approach along the lines of the suggested approach, principally on the ground of absence of "fit". In his view, the approach is not consistent with the case law; he says that it involves a change to the law of contract "in the most radical terms". ${ }^{97}$ Here it is useful to return to the contrast between the concrete legal rules that specify the outcomes on given facts, and a more general, theoretical account of the law that is thought to support these rules, including the principle of liability that is taken to provide the foundation for a doctrinal category. It is true that the way in which the principle of liability in contract is understood in the case law and literature generally reflects the standard analysis rather than the suggested approach. In particular, of course, it is normally said that the primary relation in contract is the right to performance and the correlative duty to perform, and this is not a correct description under the suggested approach. ${ }^{98}$ As pointed out above, under the suggested approach, it would be more apt to say that a contracting party's primary right is correlated with the other party's "primary liability".

\footnotetext{
97 Baloch, above n2, 64; for similar criticisms see Barker, above n63, 233-4.

98 As Baloch points out; and similarly the understanding of the rationale for expectation damages: Baloch, above n2, 64-7; see also Barker, above n63, 233-4.
} 
However, the standard analysis does not do as well as the suggested approach, I have argued, when it comes to explaining the concrete rules governing the remedies that arise out of a contract. The suggested approach provides a good account of the remedial regime in contract, including the most fundamental feature of contract remedies, the combination of the availability of the expectation measure and the non-availability of specific performance in the usual case, and it explains how there can be a claim for a restitutionary remedy, and why, consistently with the current view, it seems appropriate for such a claim to be more widely available.

Furthermore, it is a strength of the suggested approach that it explains restitutionary remedies in the contractual context as part of a single integrated account of the whole remedial regime in contract. The various remedies all arise out of the same contractual relation and give effect to the same scheme of allocation of risk, each remedy being the appropriate one in the particular circumstances in which it is available. The unjust enrichment account of the restitutionary remedies treats them as separate from the contractual regime. This would mean that, in circumstances where there is the possibility of a restitutionary remedy, contracting parties are subject to a different allocation of risk with respect to contractual performance from the one laid down by the contract, and this would tend to subvert the contractual regime and the parties' agreement. Furthermore, since it is not always predictable if and in what way a contract will come to an end, and so what sort of remedy might be available, the two regimes operating together are liable to create an unstable and unpredictable allocation of contractual risk. ${ }^{99}$

\section{Contract and reliance}

\footnotetext{
99 Cf A Kull, "Restitution as a Remedy for Breach of Contract" (1994) 67 Southern California Law Review 1465. This is so even if straightforward inconsistency between the unjust enrichment regime and the contract regime is avoided by the condition that the claim in unjust enrichment for a restitutionary remedy can arise only once the contract has terminated. e.g. Virgo \& Beatson, above n37; Virgo, above n8, 310.
} 
On the suggested approach, the basic entitlement of contracting parties is to protection for the contractual reliance interest. One might regard this approach as a version of the reliance theory of contract, and on this point there may be room for misunderstanding. First, as mentioned above, the contractual reliance interest protected under the suggested approach is not simply the interest in being restored to the status quo ante by compensation for reliance losses, which is how "reliance interest" is generally understood in contract; ${ }^{100}$ and, secondly, the suggested approach does not reject the voluntary character of contract, as the reliance theory may be understood to do. ${ }^{101}$

Contract law is voluntary, as the standard analysis recognises, in the sense that by making an agreement the parties choose to be bound, and they set the terms of the legal relationship between them. The reliance theory of contract is liable to be equated with the theory of "death of contract" or "contract-as-tort". According to this theory, the relationship between contracting parties is not, strictly speaking, created by their agreement, and claims are not based on the principle that parties are bound by what they have agreed. Instead, the true principle of liability is taken to be the principle of negligence in tort, as it applies with respect to reliance loss, or possibly some other non-contractual reliance principle. ${ }^{102} \mathrm{~A}$ claim for reliance loss arises from the fact that $\mathrm{D}$ has acted unreasonably vis-à-vis $C$ by inducing reliance through the agreement and then failing to carry it out, and the agreement is merely a factor to be taken into account in the assessment of reasonableness. It is not conclusive of liability, and furthermore it is not a prerequisite for a claim, since $D$ can be liable in respect of reliance he has induced without an agreement. On this approach, contract law is not a distinct doctrinal category based on the principle of agreement.

\footnotetext{
100 Fuller \& Perdue, above n33; McLauchlan, above n28.

101 Barker criticises the suggested approach on the ground that it is unrealistic and involves a fiction because it departs from the conventional understanding of what an agreement is: above n62, 234. But unlike the death of contract approach, the suggested approach does not abandon the crucial requirement for a non-fictional account of contract, which is that it is based on actual agreement. 102 The death of contract theory is associated with Atiyah, above n53, and Promises, Morals, and Law (Clarendon Press, 1981), and G Gilmore, The Death of Contract (Ohio State University Press, 1974). For a recent discussion, see C Bridgeman \& John CP Goldberg "Do Promises Distinguish Contract from Tort?" 45 Suffolk University Law Review 873 (2012).
} 
The death of contract theory might be able to account in some circumstances for the remedies that are available in contract, including the expectation measure, on the basis of the opportunity cost argument, along similar lines to the suggested approach. However, the death of contract theory cannot explain the contractual valuation and the allocation of risk entailed in the contractual valuation. ${ }^{103}$ Furthermore, the reliance interest protected under the death of contract approach is simply the interest in compensation for reliance loss, whereas the contractual reliance interest protected under the suggested approach is a right to a return on performance in accordance with the contractual valuation, which includes but goes beyond compensation for loss incurred. Thus the death of contract theory cannot explain the quantum meruit, except as a noncontractual claim for payment for a benefit conferred, i.e., an unjust enrichment claim. The death of contract theory in effect replaces contract with a combination of contract-as-tort to allow for claims for compensation for reliance loss, and contract-as-unjust-enrichment, to allow for claims for payment for a benefit conferred. ${ }^{104}$ Unlike the suggested approach, it does not in fact amount to a genuine alternative to the unjust enrichment approach.

Supporters of the usual unjust enrichment approach regard unjust enrichment as separate from and complementary to contract. Even if it is regarded as a separate and complementary, however, the usual unjust enrichment approach does, in its practical effect, give partial recognition to the death of contract approach, because it treats a claim for a restitutionary remedy as non-contractual when in reality it is contractual (i.e., agreement-based, as the suggested approach shows). When there is a valid contract in place governing the provision of a benefit, the unjust enrichment approach supports the recognition of a claim for payment for the benefit or some part of it that may be at odds with the parties' agreement, and in principle, like the death of contract theory, it has

\footnotetext{
103 This was attempted by Atiyah, ibid, 184ff, in the form of "promises as admissions", criticised by J Raz "Promises in Morality and Law" 95 Harvard Law Review 916 (1982).

104 Atiyah, above n53, 768.
} 
no room for the contractual valuation. It even denies that it is relevant for the purposes of such a claim whether or not there is actually a valid contract governing the provision of the benefit: ${ }^{105}$ it makes no distinction between the claim for payment for a benefit that arises when there is a valid contract, and such a claim when the contract is void. Like the death of contract theory, the unjust enrichment approach subverts the role of agreement in contract and undermines the distinction between contractual and non-contractual claims. The death of contract theory and the unjust enrichment approach are misconceived for essentially the same reason, ${ }^{106}$ and it is actually the unjust enrichment approach, not the suggested approach, that suffers from the defects of the theory of death of contract.

The voluntary character of contract under the suggested approach

The death of contract theory is not how I mean the approach suggested here to be understood. The approach I suggest treats contract as voluntary and based on agreement, ${ }^{107}$ just as the standard analysis does. The difference between the two approaches lies in the way they understand the form of the agreement. The two

\footnotetext{
105 See e.g. Baloch, above n2, 179-80, Burrows, above n8, 319.

106 Though of course the two positions have been presented in mutual opposition, in particular in Atiyah, above n53, 764ff and PS Atiyah Essays on Contract (Clarendon Press, 1986), 47ff, and P Birks, "Restitution and the Freedom of Contract" (1983) 36 CLP 141. Another argument for the death of contract approach has featured in the literature. There are a number of controversial cases, including the "pre-contractual" cases mentioned earlier, in which a claim for payment for a benefit conferred has been allowed in the absence of a binding contract, e.g. British Steel Corp v Cleveland Bridge and Engineering Co Ltd [1984] 1 All ER 504; William Lacy (Hounslow) Ltd v Davis [1957] 2 All ER 712; Pavey \& Matthews Pty Ltd v Paul (1987) 162 CLR 221. See e.g. Virgo, above n8, 342-52. Hedley has suggested that these types of case can be explained as contractual claims by adopting a wide, artificial sense of contract, not limited to cases of actual agreement and extending to cases that should be treated as if there were an agreement because they are analogous. The basis of the extended category of contract is not agreement, but the protection of induced reliance: see $S$ Hedley, A Critical Introduction to Restitution (Butterworths, 2001), 47-9; S Hedley, "Implied Contract and Restitution" [2004] CL] 435; S Hedley, Restitution, Its Division and Ordering (Sweet \& Maxwell, 2001), 55. Hedley refers to the "express contract fallacy", the supposed fallacy of basing contract on genuine agreement, alluding to the old implied contract fallacy. At one time it would have been said that these claims were based on implied contract and supporters of the theory of unjust enrichment argue that their theory has supplied a genuine basis for such claims that has allowed the law to escape from the implied contract fallacy, whereas Hedley's approach can be understood as a way of rehabilitating the implied contract approach. In some of these types of case, the claim is based on an agreement that is not recognised as contractual, and here it does seem that the claim should be recognised as contractual: see Jaffey, above $n 12$, ch 3 .

107 There is another version of the reliance theory of contract, according to which, although contractors have promised to perform, they should not be compelled to do so, because compelling people to provide benefits, even when they have promised to do so is an intrusion on individual autonomy, and so legal protection for contracts should be confined to the reliance interest: see Raz, above n102; cf Kimil, above n92.
} 
forms of agreement, agreement by exchange of promises of performance and agreement by mutual assumption of responsibility for reliance, in principle give rise to different primary legal relations between the parties, which should in principle give rise to different remedial regimes, consisting of the remedies that are appropriate to vindicate the primary relation in the various circumstances of contractual non-performance. It was suggested above that an agreement in the form of promises of performance should normally support a right to specific performance, in the first place, and a right to the expectation measure in the alternative, but no right to a restitutionary remedy, whereas an agreement in the form of a mutual assumption of responsibility for reliance under the suggested approach would normally support a right to the expectation measure and a right to a restitutionary remedy, but normally no right to specific performance. It was argued above that the suggested approach is closer to the established remedial regime, and also supports the recent trend for the expansion of restitutionary remedies. By contrast, it is sometimes argued, consistently with the standard analysis, that the established remedial regime in contract is deficient in excluding a general right to specific performance and that the law should be developed to correct this. ${ }^{108}$ According to the argument above, these should be understood as opposing positions on the form of agreement that contracting parties employ in practice.

Which regime better reflects the form of agreement that contracting parties actually employ? Do contracting parties actually understand themselves, as the standard analysis presupposes, to be making a promise to carry out their part of the agreed exchange, by virtue of which they become subject to a duty to do so, so as to give rise to a genuine requirement to act in that way, and so that they act wrongfully if they fail to do so? Or do contracting parties actually make a different form of agreement, as the suggested approach presupposes, by which they think of themselves as proceeding on the basis of an allocation of risk

\footnotetext{
108 As argued in Shiffrin, above n 60, which assumes what I have described as the standard analysis.
} 
relating to the investment of resources and labour involved in carrying out the exchange, each party accepting responsibility for the other party's investment, which is usually satisfied by carrying out the exchange but otherwise can give rise to a pecuniary liability? ${ }^{109}$

Some would insist that contractual agreements consist of promises of performance, and no doubt this is how agreements are normally understood in the textbooks and the literature, but I do not think it is clear that this is the better description of what contracting parties do in practice. One might seek to investigate this as an empirical question in social science, and indeed there have been studies of some relevance to this, though the question as stated above does not appear to have been addressed directly. ${ }^{110}$ One might also consider what form of agreement reasonable contracting parties would be expected to adopt. Under the standard analysis, by requiring each party to perform and giving each party the right to receive performance, the agreement goes further than is necessary for the exchange to proceed. Compared with the standard analysis, an agreement under the suggested approach provides less security for the recipient of a benefit, because he has no right to the provision of the benefit, but more flexibility for the provider, who has no duty to provide it, and is free to abandon the contract. This arrangement may be preferable to contracting parties if on the whole they value the greater flexibility of the suggested approach over the greater security of the standard analysis. ${ }^{111}$ An argument along these lines might suggest that

\footnotetext{
109 One might say that this could be put more simply by saying that each party promises to take responsibility in this way, i.e. promises to satisfy the contractual reliance interest. I do not think this is the right way of putting it, but in any case the crucial point is that the parties do not promise to carry out the exchange, and, in the ordinary case, do not have duties to do so.

110 Some empirical studies examine the practices and expectations of business people, as famously in S Macaulay, "Non-Contractual Relations in Business: A Preliminary Study" 28 Am Soc Rev (1963), and others the sense ordinary people have about what the law should require, as for example in $T$ Wilkinson-Ryan " Do Liquidated Damages Encourage Breach? A Psychological Experiment" 108 Michigan Law Rev 633 (2010). Contracting parties with experience or knowledge of enforcement may have a sense that the established remedial regime is appropriate to vindicate agreements, so that the allocation of risk implicit in what is agreed is also the allocation of risk enforced by the law; or instead they may have a sense of a mismatch or dissonance between what is agreed and the established remedial regime. If, as was argued above, the established regime is closer to the suggested approach, and if there is no evidence of a general sense of mismatch or dissonance, this would give some support to the suggested approach.

111 The famous "efficient breach hypothesis", the first appearance of which is attributed to R Birmingham, "Breach of Contract, Damage Measures, and Economic Efficiency" 24 Rutgers Law Review 273 (1970), was advanced to explain the absence of specific performance to compel
} 
contracting parties might be expected to adopt the form of agreement under the suggested approach.

For a court dealing with a particular dispute, if it were to accept the distinction in principle between the two forms of agreement, one line to take would be to treat the determination of the form of agreement as a matter of interpretation to determine the intentions of the parties. This would in principle govern the remedial regime that should apply. The exercise of interpretation would involve inferring the form of agreement from the general understanding and expectations of the parties. Although the courts have not explicitly addressed the issue in the past, it would be reasonable to presume, subject to contrary evidence, that the form of agreement that contracting parties generally employ is the form of agreement that the established remedial regime is generally apt to vindicate. Since the established remedial regime is closer to the suggested approach, the law should presume that the agreement involves the acceptance of responsibility for reliance, and that the established remedial regime should be developed to give fuller effect to the suggested approach, including the expansion of restitutionary remedies.

Of course, although some remedial matters can be provided for by the parties, in general the remedial rules are understood as an ordinary matter of law, not dependent on an interpretation of the contract to determine the intentions of the parties. An alternative line to take, more in keeping with this, would be to treat the form of agreement open to contracting parties as a matter determined by the law, and merely reflected in the practices and expectations of contracting parties. Again, since the established remedial regime is closer to the suggested approach, the implication is that the form of agreement actually recognised by the law is agreement to accept responsibility for reliance. It might be controversial which form of agreement the law should adopt - whether it

performance, and is usually presented as supplying a justification for the wrongful breach of contract on grounds of economic efficiency, but it would be better to understood it as holding that a contractual regime under which it is not wrongful to withdraw and pay damages - as under the suggested approach - would be preferable on efficiency grounds. 
should favour security for the recipient of a benefit or flexibility for the provider but, as things stand, the development of the law by analogy to promote coherence would again require the courts to develop the law to give fuller effect to the suggested approach, including the expansion of restitutionary remedies.

More fundamentally, whatever the remedial regime should be in contract, the focus of inquiry with respect to restitutionary remedies, just as for the other, ordinary contract remedies such as expectation damages or specific performance, should be on contract law, on the nature of the agreement and the legal relation it creates, and on the remedies that are appropriate in different circumstances to vindicate it. By contrast, the unjust enrichment approach does not offer a plausible non-contractual account of restitutionary remedies in contract. 